\title{
The Impact of COVID-19 on Pilgrimages and Religious Tourism in Europe During the First Six Months of the Pandemic
}

\section{Franciszek Mróz ${ }^{1}$ []}

Accepted: 29 January 2021 / Published online: 21 February 2021

(c) The Author(s), under exclusive licence to Springer Science+Business Media, LLC part of Springer Nature 2021

\begin{abstract}
This study presents the results of the examination of the influence of the SARSCov-2 coronavirus pandemic on religious tourism and pilgrimages to selected Catholic pilgrimage sites in Europe during the first six months of the COVID-19 pandemic (March-September 2020). Field research conducted in shrines and on several pilgrimage routes involved interviews with shrine custodians and staff as well as pilgrims. Data regarding tourism and pilgrimage movement were also gathered. Research results have shown that the tourism and pilgrimage movement to the analysed shrines decreased by 90-95\% during the first six months of the pandemic. The shrines in Santiago de Compostela and Lourdes were closed for a few weeks during the first wave of coronavirus spread. The influence of the pandemic on the age structure of pilgrims is noticeable, with a distinct decrease in the number of pilgrims aged $60+$. Also, the reasons for pilgrimages to shrines have changed. The overriding principle followed by shrine custodians and organisers of pilgrimages was to ensure the safety of pilgrims on their way to shrines and, most importantly, in the shrine areas. The largest Catholic shrines in Europe encouraged pilgrims to deepen their bonds with the shrine through participation in online services and prayers and to pursue spiritual and virtual pilgrimages. The study also shows a model of the development of pilgrimages and religious tourism during the COVID-19 pandemic.
\end{abstract}

Keywords COVID-19 pandemic $\cdot$ Pilgrimages $\cdot$ Pilgrimage space $\cdot$ Shrine $\cdot$ Pilgrimage route $\cdot$ Virtual pilgrimage

Franciszek Mróz

franciszek.mroz@up.krakow.pl

1 Department of Tourism and Regional Studies, Institute of Geography, Pedagogical University of Krakow, ul. Podchorążych 2 (room 526), 30-084 Kraków, Poland 


\section{Introduction}

Pilgrimages to holy sites are considered to be the oldest form of tourism (Apollo et al. 2020; Chélini \& Branthomme 1982; Collins-Kreiner 2010, 2015; Timothy $\&$ Olsen 2006). These have contributed to the development of geographic, cultural and civilisational horizons of nations in all religions of the world (Eliade 1969; Jackowski 2003; Singh 2004). Pilgrimages are complex and changeable phenomena composed of a set of mutual interactions of religious, lay and natural factors occurring in the geographic space of pilgrimages (Cohen 1992; Coleman \& Eade 2004; Collins-Kreiner 2010, 2007; Digance 2003; Eade \& Sallnow 1991; Kaszowski 1996). Such areas are mainly characterised by the diversity of geographic environment elements and dynamism-lack of stability, variability in time, clearly visible during the COVID-19 pandemic.

Religious tourism belongs to the best developing forms of global tourism. In accordance with the data of the World Tourism Organisation (UNWTO), approximately 330 million people go on religious or religious and cognitive tours each year and they visit major pilgrimage centres worldwide (www.media.unwto .org; Griffin \& Raj 2017; Scaffidi Abbate \& Di Nuovo 2013). The promotion of shrines, the seeking of sites to meet "oneself" and God, the renewal of tours along pilgrimage routes, the appearance of new pilgrimage routes, the development of the automotive industry and the extension of tourism infrastructure in pilgrimage centres are the factors influencing the development of pilgrimages and religious tourism (Roszak 2017; Mróz 2019a).

The global pandemic caused by the SARS-CoV-2 coronavirus has already affected more than 45 million people from 190 countries and territories in the world (data as at 31 October 2020). The effects of the pandemic have and will surely still have for a long term an immense impact on the economy, education, health, religion, culture, tourism, sports and social and psychological behaviours of people all over the world (Oxholm et al. 2020). Due to the second wave of the COVID-19 pandemic, in the next few months we can expect further considerable changes in the world economy and in our daily lives, work, education, relaxation and recreation. We are unable to clearly define which stage of the pandemic we are currently at and what our world will look like after it subsides.

The space for pilgrimages, the sacred space of thousands of shrines worldwide, changed hour after hour during the first days of March. The next weeks turned out to be disastrous for pilgrimages. COVID-19 brought isolation, uncertainty, pain, suffering and deaths of thousands of people. The scenes of the closed Church of the Nativity in Bethlehem (closed from 5 March to 24 May 2020), the Church of the Holy Sepulchre in Jerusalem (closed from 25 March to 24 May 2020), Major Basilicas in Rome, Pope Francis praying in solitude in St. Peter's Square during the Paschal Triduum, the deserted pilgrimage route to the Shrine of St. James in Santiago de Compostela, the empty Massabielle Cave in Lourdes, hundreds of thousands of closed temples and shrines of all religions worldwide really moved religious people. The passion services, Passion Plays and celebrations of the 
Paschal Triduum were cancelled. Justin Welby, the Archbishop of Canterbury, celebrated the Easter service broadcast online from his flat in London.

As early as in the first weeks of the pandemic, the leaders of the major religions and denominations requested their followers to keep social distancing, to help those in need, to avoid leaving homes and to participate in services and prayers via mass media, mainly the Internet (social media) and television. A lot of projects associated with religious and cultural events in shrines have been reduced to zero. This is an unprecedented event after WWII-nothing else has affected tourism, including religious tourism and pilgrimages, as much as the COVID-19 pandemic.

This study presents the results of research on the influence of the SARS-Cov-2 pandemic on religious tourism and pilgrimages to selected Catholic pilgrimage centres in Europe during the first six months of the COVID-19 pandemic (March-September 2020). It is a kind of an "opening report" as it covers a relatively short period of time when the first symptoms of the reactivation of pilgrims to the analysed centres were observed from mid-May and in case of the Camino de Santiago pilgrimage route in Spain as late as from 1 July 2020.

This is an important research problem considering the scale of the influence of the COVID-19 pandemic on the pilgrimage space and the functioning of thousands of sacred places worldwide. Another reason why it is so important is the unfortunately rapid development of the COVID-19 pandemic from October 2020. From the perspective of the finalisation of work on this publication (31 October 2020), it is clear that the analysed six months were the period of the first wave of the pandemic. Since early October 2020, record numbers of cases have unfortunately been noted in individual countries in the world; on 31 October 2020, the total global number of coronavirus cases diagnosed that day exceeded 560 thousand (https://gisanddata .maps.arcgis.com). It can be concluded today that the results of research presented in this paper will trigger further research on the influence of the COVID-19 pandemic on pilgrimages and religious tourism in the following months of 2020 and 2021.

\section{Materials and Methods}

The analysis covers the largest Catholic shrines in Europe: Santiago de Compostela, Lourdes, Częstochowa, Kraków-Łagiewniki and Wadowice (Table 1). They were not chosen randomly. Lourdes and Jasna Góra belong to the largest and most important pilgrimage centres worldwide, and along with Fatima, they are also the largest centres of Marian cult in Europe (Jackowski 2005). Before the COVID-19 pandemic, Lourdes and Jasna Góra had been visited by approx. 5 million people each year. The Shrine of Divine Mercy in Kraków-Łagiewniki, in turn, is the world centre of divine mercy veneration, whereas the Shrine of St. James, the Apostle in Santiago de Compostela, and Wadowice, the papal town of St. John Paul II, belong to the most popular shrines associated with the cult of saints-St. James the Greater and St. John Paul II. Thus, referring to the most popular categorisation of Christian centres of religious cult into three groups (shrines of Lord, Marian shrines and shrines of saints and blessed) (Mróz,) individual shrines selected for the purposes of analysis represent each of these groups-Lourdes and Jasna Góra are Marian 


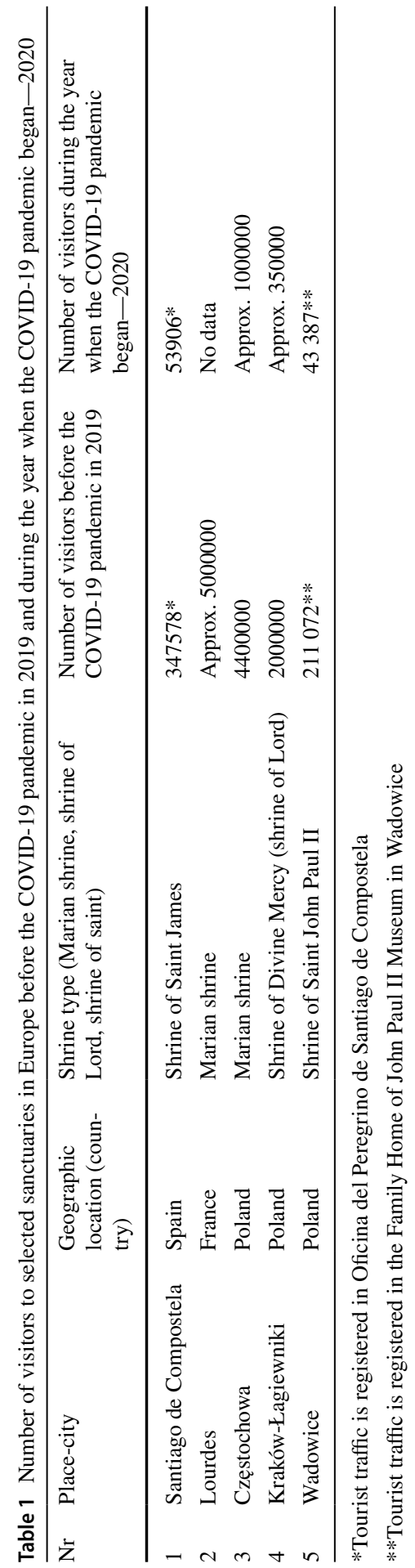


shrines, Kraków-Łagiewniki is the shrine of Lord, while Santiago de Compostela and Wadowice are shrines of saints. Their international importance (range of geographic impact) has been the factor decisive for choosing these shrines. Each year, these are visited by pilgrims or tourists from more than 80 countries (Griffin \& Raj 2017; Mróz 2019a).

The detailed data regarding tourist pilgrims in the last few years and in the first six months of the SARS-Cov-2 coronavirus pandemic (which the author is most interested in) were retrieved from the Office of Pilgrims at Santiago de Compostela (Oficina del Peregrino de Santiago de Compostela), from the Press Office of Jasna Góra and the Family Home of John Paul II in Wadowice. The gathered statistical material has been structured and systematised. The comparative method as well as descriptive and analytical methods have been used to present research results. Cartographic presentation methods (choropleth maps) and graphic presentation methods have been applied for the elaboration of quantitative data.

Interviews with custodians and employees of shrines and pilgrims were utilised as part of this research. Pilgrims were interviewed in Santiago de Compostela, in Wadowice and in Kraków-Łagiewniki. Field research was also conducted, namely observations in Santiago de Compostela, in Shrine of Our Lady of Częstochowa, in Shrine of Divine Mercy in Kraków-Łagiewniki, in the papal town of Wadowice and on several sections of the Way of St. James. These qualitative data however are not included within this article as it will be presented in a subsequent paper. One of the primary goals of this study was to develop an explanatory model regarding the pilgrimages and religious tourism during the COVID-19 pandemic.

\section{Results}

\section{Shrine of St. James in Santiago de Compostela and the Way of St. James}

The Shrine of St. James in Santiago de Compostela is considered to be one of the oldest and most important Christian pilgrimage centres (Adamczyk 2011; Cazaux 2011; Jackowski, Mróz 2012; Roszak, 2019). During the thirteenth century, the route going to the Cathedral in Compostela was covered each year by 500 thousand pilgrims (Murray \& Graham 1997). Since the 1980s, an impressive development of the Way of St. James_Camino de Santiago has been noted (Gusmán et al. 2017). The route is also known as the "most beautiful way in the world", "the main street in Europe", "the way of life"- the road in which thousands of people search for a chance to meet "themselves"— to look deep inside and meet God (Roszak 2017; Mróz et al.2019). Currently, the Camino de Santiago network covers more than 80 thousand kilometres of the marked route.

From the 1990s until the outbreak of the COVID-19 pandemic, tourism and pilgrimages along the pilgrimage route to Compostela developed dynamically. In recent years, more than 300 thousand Camino fans walked to Santiago de Compostela (Mróz 2017). The year 2019 was the record year in terms of the tourism in Camino de Santiago. The Oficina del Peregrino de Santiago de Compostela noted 
a record (in modern and contemporary times) number of 347,578 Camino pilgrims from more than 180 countries worldwide (http://oficinadelperegrino.com).

2020 was forecast to bring another record in terms of the number of tourists and pilgrims in Camino de Santiago. Various events were planned in Santiago de Compostela for 2020 to precede the next Compostela Holy Year (Año Santo Jubilar Compostelano), which is to begin in Santiago de Compostela on 31 December 2020. The data concerning the pilgrimage/tourism movement to the Shrine of St. James in Compostela during the first two months of 2020 indicated that the current year would bring record in terms of the number of pilgrims in Camino de Santiago. In January and February 2020, the highest numbers of Camino pilgrims were recorded in Oficina del Peregrino de Santiago de Compostela—1,999 and 3,076, respectively (http://oficinadelperegrino.com) (Fig. 1).

As was mentioned at the beginning, on 13 March 2020, the Government of Galicia ordered that the route to Santiago de Compostela-shelters, hostels, hotels, bars and restaurants in Camino de Santiago as well as discos, shopping malls, hardware stores (except for pharmacies and food stores) should be closed. Subsequently, on 14 March 2020, after the session of the Council of Ministers, Prime Minister Pedro Sánchez announced the state of emergency throughout Spain by way of the special Royal Decree (Bordas Prószyński 2020). The state of emergency was prolonged in Spain a few times and pursuant to the decision of the Government, it came to an end on 21 June 2020 (when 245,938 coronavirus cases and 28,322 deaths due to coronavirus were noted in Spain, https://www.rtve.es/noticias/coronavirus-graficos-mapas -datos-covid-19-espana-mundo/).

The gradual reopening of the pilgrimage route to Santiago de Compostela-a network of shelters, hostels, hotels, restaurants near Camino de Santiago—started on 1 July 2020. On that day, the Cathedral of St. James and the Office of Pilgrims were opened but with the number of people attending a Holy Mass restricted to 75 only.

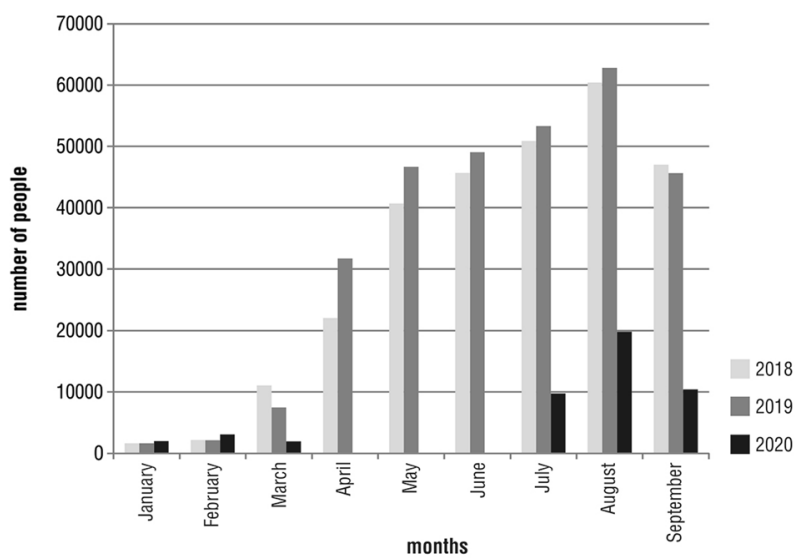

Fig. 1 The number of Way of St. James pilgrims recorded in the months of January - August 2018, 2019 and 2020. Source: own study based on data made available by Oficina del Peregrino de Santiago de Compostela 
Archbishop Julián Barrio "symbolically" greeted pilgrims in front of the Cathedral in Compostela. The Government of Galicia, in turn, prepared a special preventive guidebook with recommendations regarding the services along Camino de Santiago (https://www.elcorreogallego.es/santiago).

The number of Camino pilgrims recorded in July 2020 was five times lower than in July 2019 (in July 2020 9,752 people, in 2019 53,319); in August 2020 it was more than three times lower than in August 2019; in September 2020, the Office of Pilgrims in Santiago de Compostela recorded 10,441 people, i.e. four times fewer than in September 2018 and 2019 (http://oficinadelperegrino.com) (Fig. 1).

The development of the COVID-19 pandemic had a considerable impact on changes in the spatial range of Camino de Santiago. Based on the data from Oficina del Peregrino de Santiago de Compostela, the range in July, August and September 2020 can be analysed in detail and the data can be compared to similar months in 2019. In July 2019, the Office of Pilgrims in Santiago de Compostela recorded 21,492 Camino pilgrims from 135 countries and in July 2020 the number was more than eleven times lower, with 1,893 foreigners from 80 countries of the world (Figs. 2 and 3). In July 2020, Spaniards accounted for more than $80 \%$ of pilgrims. In comparison, in July 2019 the share of Spanish people in total pilgrimages was definitely lower and amounted to 58.6\%. It should be recalled that

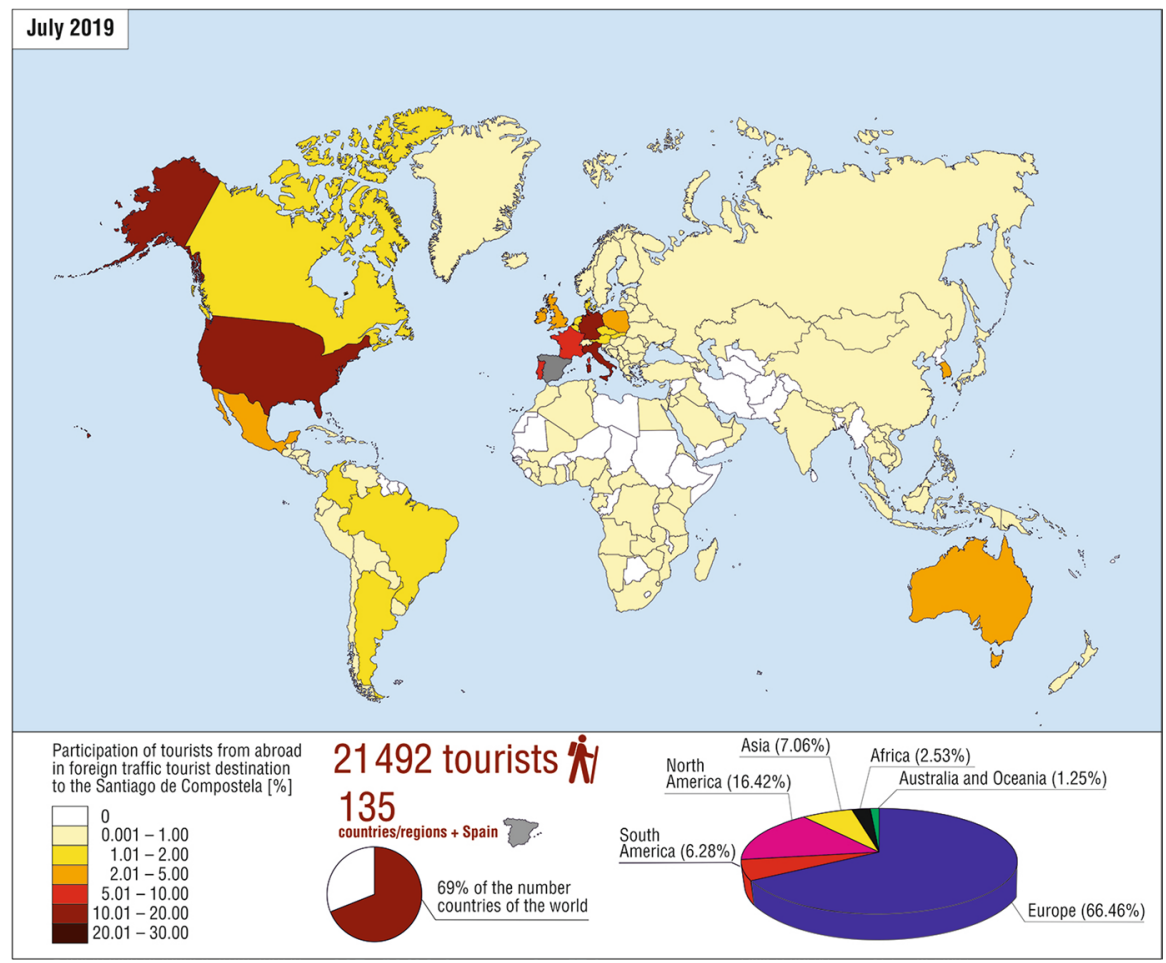

Fig. 2 Foreign tourists wandering on the Way of St. Jakub to Santiago de Compostela in July 2019. Source: own study based on data made available by Oficina del Peregrino de Santiago de Compostela 


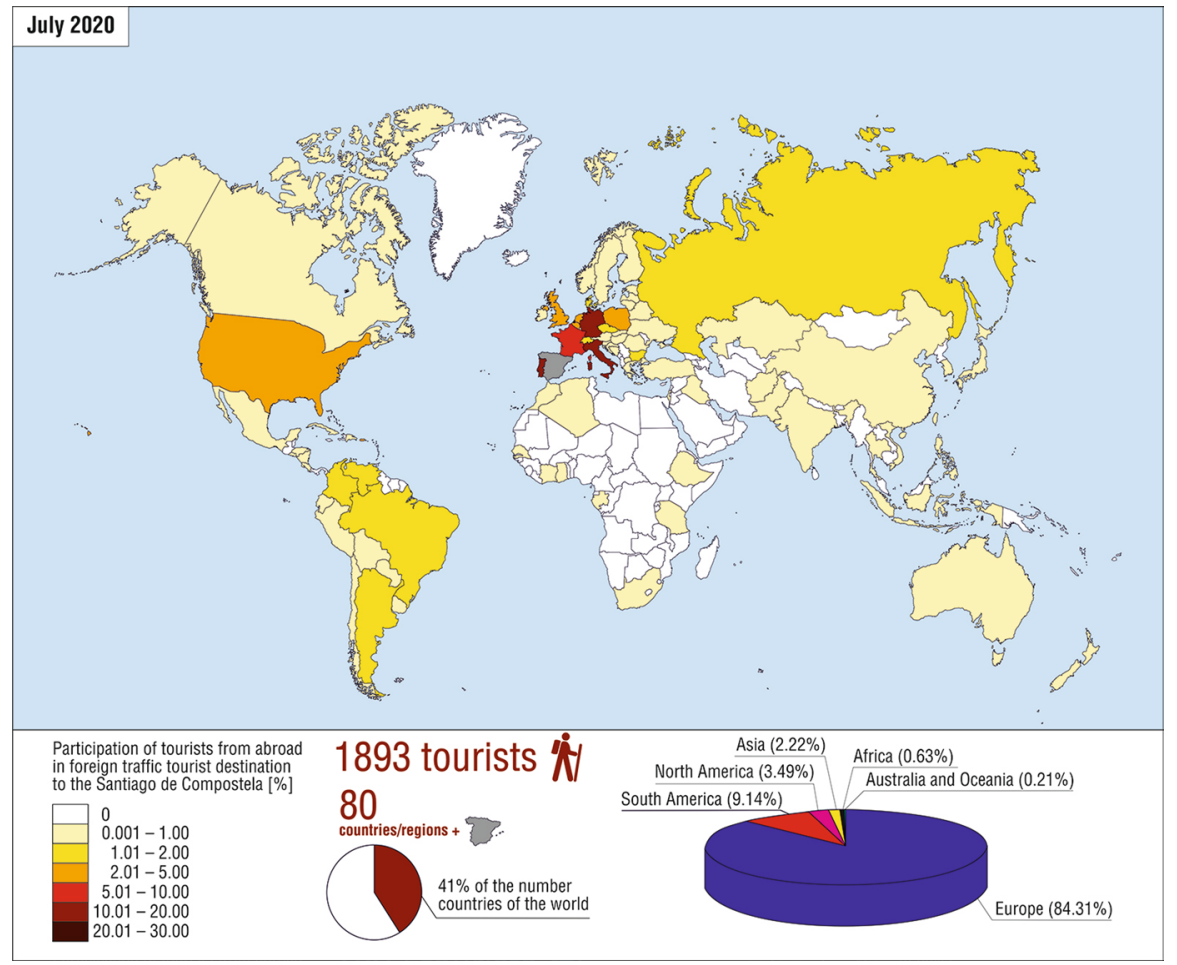

Fig. 3 Foreign tourists wandering on the Way of St. Jakub to Santiago de Compostela in July 2020. Source: own study based on data made available by Oficina del Peregrino de Santiago de Compostela

Spain opened its borders on 24 June 2020 and many flight routes were still suspended even then. In July 2020, the share of Camino pilgrims from non-European countries was also decreased (Fig. 3). In August 2020, the number of foreign Camino pilgrims increased to 4644 people from 94 countries, but this was more than 5 times less than in August 2019 (26,249 people). In September 2020, the Office of Pilgrims recorded 3,166 Camino pilgrims from 82 countries, whereas the numbers for September 2019 were the following: 29,223 foreigners from 128 countries (http://oficinadelperegrino.com).

In recent years, the share of people aged $60+$ registered by the Office of Pilgrims in Santiago de Compostela increased, with $9.1 \%$ in $2004,14.8 \%$ in $9.1 \%$, $17.4 \%$ in $2017,18.3 \%$ in 2018 and $18.7 \%$ in 2019 (http://oficinadelperegrino. com). In July, August and September 2020, the percentage share of people aged $60+$ was considerably lower than in similar months during the period 2018-2019 (http://oficinadelperegrino.com). This change can be explained by the fear of the elderly that they can catch coronavirus. People who have turned 70 are more inclined to suffer a more serious course of COVID-19 infection and this age group is unfortunately characterised by the highest mortality rate in consequence of complications (Fig. 4). 


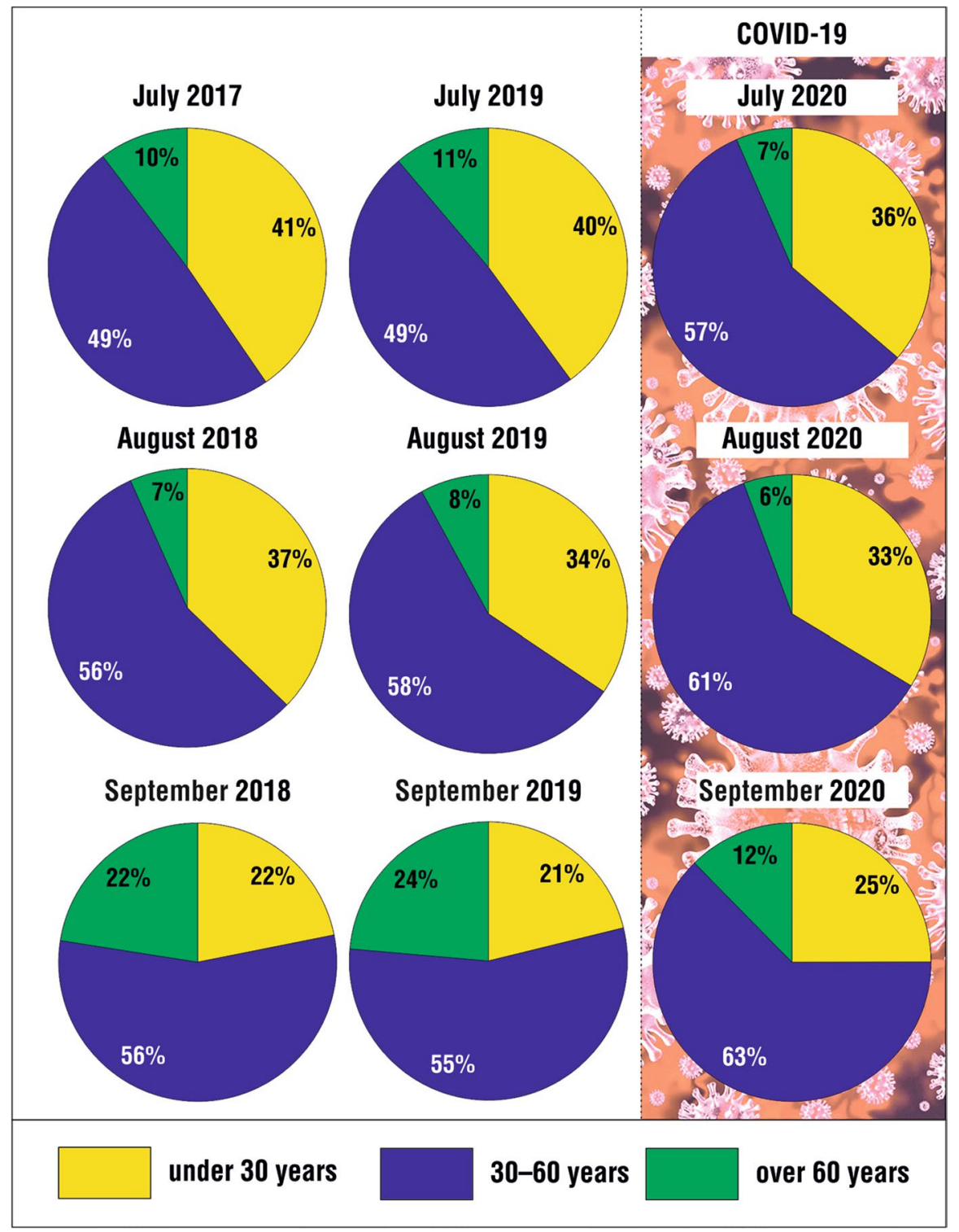

Fig. 4 Age structure of tourists / pilgrims wandering on the Way of St. Jakub to Santiago de Compostela in July, August and September in 2017-2020. Source: own study based on data made available by Oficina del Peregrino de Santiago de Compostela

The impact of the COVID-19 pandemic is also noticeable on the motives for travelling to Santiago de Compostela. In July, August and September 2020, a considerable decrease in the share of Camino pilgrims going along the Way of St. James for 


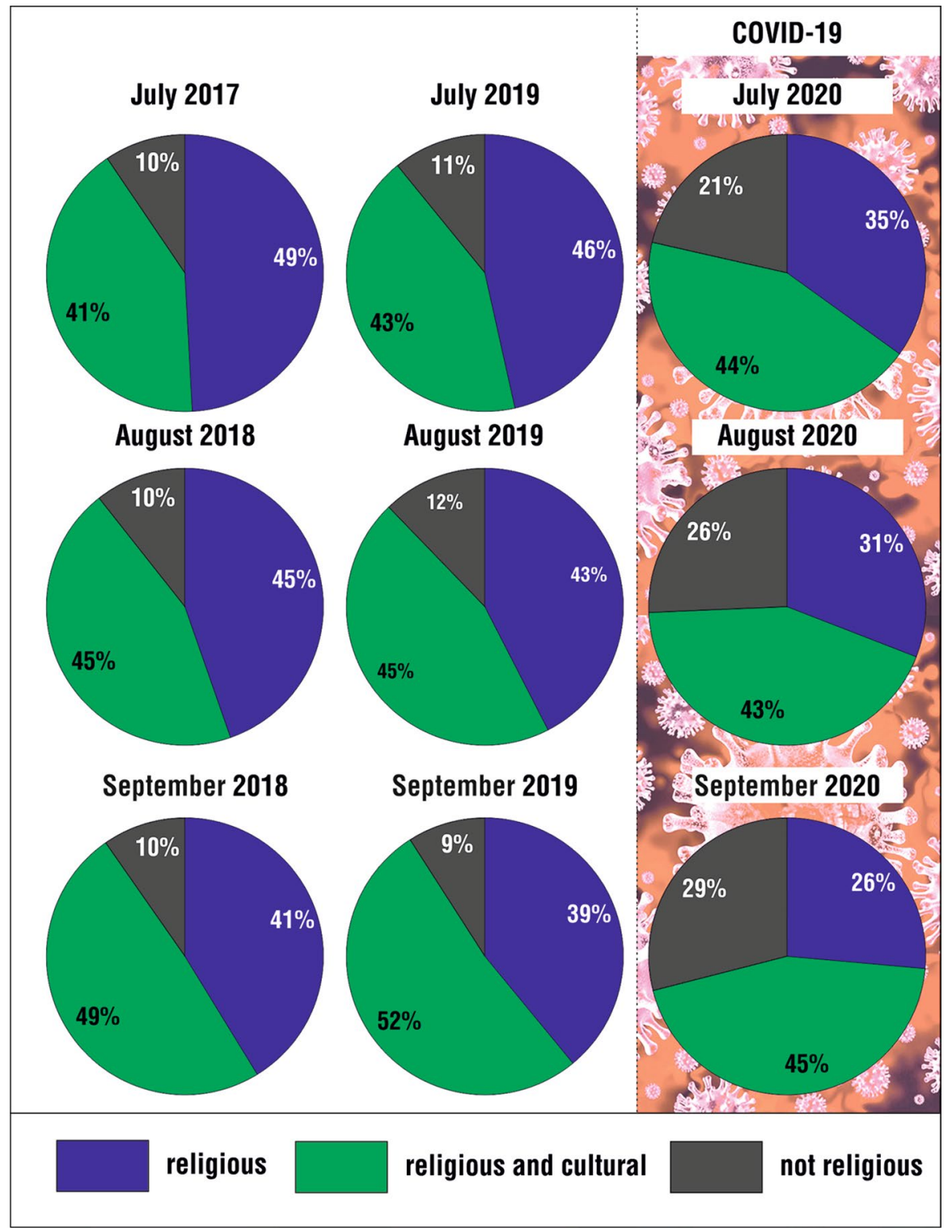

Fig. 5 Motives for travels of tourists / pilgrims wandering on the Way of St. Jakub to Santiago de Compostela in July, August and September in 2018-2020. Source: own study based on data made available by Oficina del Peregrino de Santiago de Compostela

religious reasons was observed. However, the share of people who went to Santiago de Compostela for non-religious reasons considerably increased (Fig. 5).

According to the accounts of pilgrims and employees of tourist companies and organisations in Camino Frances and Camino Primitivo, after 1 July 2020 almost 
all churches and chapels along the route were closed (except for the cathedrals in Oviedo, Lugo, Santiago de Compostela and the Church of St. Peter in Melide). Only one third of restaurants and bars functioned along the route, but most of the restaurants in towns were open. All municipal shelters (albergue) and the majority of parish shelters were closed. Almost all of private shelters and hostels were open, but pilgrims had their body temperature tested at the reception desk. Mouth and nose had to be mandatorily covered in shelters, hand disinfection and replacement shoes were also obligatory.

It is worth pointing at an interesting tendency which began during the COVID19 pandemic and is associated with pilgrimage routes of regional and international importance in Europe. The number of pilgrims wandering along transborder routes (Way of St. James, Via Francigena) has been reduced several times during the COVID-19 pandemic in comparison with previous years. The number of pilgrims on the French section Via Francigena during the pilgrimage season in 2020 was ten times lower. Thousands of pilgrims who were planning to go along Camino in 2020 abandoned their plans and chose local routes-national or regional sections of Camino de Santiago or other pilgrimage routes to regional shrines. Field research conducted during the holiday season in the Polish sections of the Way of St. James-Camino Polaco, the Pomeranian Way of St. James and the Way of St. James Via Regia and interviews with route coordinators incline the author to conclude that tourism along these sections was higher in July and August 2020 than in the similar period in 2019. In accordance with the data from the Road Association at Mont-Saint-Michele, the number of pilgrims on the routes going to the shrine of Michael Archangel was in this year higher by $20-30 \%$ than in the previous year (Bronk 2020).

\section{Sanctuary Our Lady of Lourdes}

The Sanctuary Our Lady of Lourdes is the largest Marian sanctuary in Europe. Until the outbreak of the COVID-19 pandemic, it had been visited by approx. 5 million pilgrims each year in the last few years (www.lourdes-infos.com). The majority of the residents of this town with the population of 14 thousand work in companies or organisations offering services to pilgrims. Lourdes is the second town in France after Paris with the largest number of hotels per square metre.

It would be hard to find another pilgrimage town in Europe equally affected by the SARS-CoV-2 coronavirus pandemic. On 17 March 2020, Rev. Olivier Ribadeau Dumas, rector of the Sanctuary of Our Lady of Lourdes, announced on Twitter that the sanctuary was to close temporarily for the first time in its history. For two months, until 16 May 2020, the Lourdes sanctuary remained closed. So were tens of hotels, restaurants and stores-almost the entire town. 95\% of pilgrimages to Lourdes were cancelled due to the COVID-19 pandemic and approx. 1.5 million out of 2.2 million accommodation reservations for 2020 were also cancelled. One third of hotels opened after 16 May were occupied in 5-8\% only (www.vaticannew s.va). According to the President of the Chamber of Commerce and Industry of the Department, François-Xavier Brunet, the crisis will have a tragic influence on the 
tourism economy of the town (https://www.ladepeche.fr/2020/04/05/75-des-peler inages-de-2020-sont-deja-annules, 8,833,317.php). Thanks to the installed counters at the entrance to the sanctuary, nearly one million passages were registered from late May to late September, which, taking into account the repeated passes of some pilgrims, the number of visitors was estimated at around 700,000 - the vast majority of individual visitors.

The sanctuary in Lourdes took various steps and realised projects to reactivate pilgrimage tourism, with the primary objective to guarantee the safety of pilgrims. In close cooperation with the French medical and health authorities, the sanctuary authorities developed protocols of pilgrim acceptance and protection. A statement by doctor Alessandro de Franciscis, President of the International Association of Doctors in Lourdes, has been published on the sanctuary website. It states that "pilgrimages to Lourdes are completely safe, even in the current circumstances" (https ://www.lourdes-france.org/en/fight-against-covid-19-the-sanctuary-doctor-speak s/). Due to the COVID-19 pandemic, pilgrims who come to the Sanctuary of Our Lady of Lourdes cannot go to the baths. However, a spiritual experience of a bath is possible-in company of an employee of the sanctuary a pilgrim can drink water from Lourdes and wash their face. The rector of the Lourdes sanctuary invites pilgrims from all over the world who cannot come to Lourdes to embark on this spiritual pilgrimage. On 16 July 2020, the first international virtual pilgrimage in the history of the sanctuary was organised in Lourdes. Pilgrims who participated in it spiritually could watch an online broadcast: prayers at the Massabielle Cave, the Holy Mass and the traditional procession with candles.

\section{Pilgrimages to the Shrine of Our Lady of Częstochowa During the First Six Months of the SARS-CoV-2 Pandemic}

The Shrine of Our Lady of Jasna Góra in Częstochowa is the most important national Catholic shrine in Poland. It is also one of the most frequently visited Marian shrines globally. The veneration of the miraculous icon of Our Lady of Jasna Góra has been developed there since 1382. Pilgrimages to the shrine developed particularly after the famous defence of the convent in Jasna Góra against Swedish troops in 1655 and after the vows of King John II Casimir who entrusted Poland to the care of the Mother of God declared to be the Queen of Poland (1/04/1656) (Jackowski 1999). In 1717, the image of Our Lady of Jasna Góra was crowned with papal crowns granted by Pope Clement XI.

Pedestrian pilgrimages to the shrine in Jasna Góra are a phenomenon of religious, social and cultural nature. Their tradition dates back to the early seventeenth century and they have rapidly developed since the 1970s (Jackowski 1999). In recent years (before the outbreak of the COVID-19 pandemic), the shrine in Jasna Gora was visited by approx. 4.5 million pilgrims each year (4.3 million in $2018 ; 4.4$ million in 2019), including around 150 thousand pilgrims on foot (www.jasnagora.com).

Due to the outbreak of the COVID-19 pandemic in early March 2020, the shrine of the miraculous image of Our Lady in the shrine in Jasna Góra was almost completely empty in March and April 2020. However, it should be emphasised that the 
shrine was not closed even during the period of the strictest restrictions. The phenomenon of pilgrimages was sustained but with a considerably smaller number of participants. Almost all pilgrimages of different age groups and professions were cancelled in March, April and May 2020. The shrine has not been visited by groups of secondary school leaving students since the outbreak of the pandemic (in 2020 the shrine recorded only 51 groups of such students who prayed at the shrine at the beginning of the year; in comparison, in 2019 Jasna Góra was visited by 278 such groups and in 2018 by 371 groups). In recent years, approximately 20 thousand children preparing for the First Communion prayed before the miraculous image of Our Lady of Jasna Góra (in 2018 - 326 groups, including 20,567 children; in 2019-239 groups, including 18,147 children). During the period of the COVID-19 pandemic, the shrine was visited by 64 groups of children preparing for the first communion (www.jasnagora.com).

Due to the imposed restrictions, detailed statistics, especially with regard to walking pilgrimages, were not kept. As observed by shrine custodians, walking pilgrimages decreased by approx. $90 \%$ in terms of the number of participants. In 2019, 300 pilgrimages on foot (with 133 thousand registered participants), 170 bicycle pilgrimages and 15 groups of running pilgrimages were noted. During the 2020 COVID pilgrimage season, 160 walking pilgrimages, 130 bicycle pilgrimages, 20 running pilgrimages and one horse-riding pilgrimage were recorded in Jasna Góra (www.jasnagora.com). The majority of these pilgrimages had a minimum number of pilgrims, i.e. the number of 50 people (later increased to 150) permitted by the Chief Sanitary Inspectorate. Walking pilgrimages were organised in the relay system or in groups with the permitted number of pilgrims or in the form of representations of priests and guides - in accordance with the "one for all" philosophy. For example, the Tarnów Pilgrimage saw pilgrims pilgrimaging for only one day. The pilgrimage was divided into three groups of 150 people each, with 450 people on the way each day for nine days. It should be also emphasised that a definitely larger number of pilgrims (than before the outbreak of the COVID-19 pandemic) took part in spiritual pilgrimages and some of them came to Jasna Góra individually for the finale of the pilgrimage. Some of the pilgrimages were subject to age restrictions-only pilgrims aged 14-65 were allowed to set off. The primary principle of the organisers of pilgrimages was to keep safety; the following rules applied: keeping distance, wearing masks, measuring temperature and using disinfectants.

\section{Pilgrimages to the Shrine of Divine Mercy in Kraków-Łagiewniki During the Dirst Six Ponths of the SARS-CoV-2 Pandemic}

The Shrine of Divine Mercy in w Kraków-Łagiewniki belongs to major Christian pilgrimage centres worldwide and during the year it attracts approx. 2 million people from more than 90 countries (Mróz 2019b). It is the world culture of the Divine Mercy devotion and the site of the special veneration of the gracious image of Merciful Jesus titled "Jesus, I trust you" and of the relics of Saint Sister Faustina Kowalska. Just like in case of the shrines analysed above, the global pandemic caused by the SARS-CoV-2 coronavirus had an immense impact on pilgrimages to this centre 
of Divine Mercy. Based on the research conducted in the shrine, it can be concluded that pilgrimages to Kraków-Łagiewniki decreased by more than $80 \%$ during the first six months of the pandemic. However, it should be emphasised that the Shrine of Divine Mercy was not closed even during the period of the strictest restrictions imposed by the government of Poland. The Chapel of Perpetual Adoration and the Basilica where Holy Masses were conducted and the sacrament of penance was celebrated remained open. It should be reminded that the state of epidemic risk was declared in the Republic of Poland on 14 March 2020 pursuant to the Regulation of the Minister of Health; the state of the epidemic was declared on 20 March 2020. On 25 March 2020, strict restrictions were imposed in Poland due to the coronavirus, including, for example, the prohibition from movement except for professional duties or satisfaction of vital needs related to daily life; the congregations of more than two people were also prohibited. Restrictions were also imposed on movement by means of public transport and on foot and participation in religious celebrations was restricted to five people. Such strict restrictions applied during the Easter time which had always been a considerably ceremonial time in Poland.

These restrictions also affected the sacred space and pilgrimages to the Shrine of Divine Mercy in Łagiewniki. The greatest impact of the COVID-19 pandemic was recorded after 25 March 2020, during the last weeks of the Lent, during the Easter time and especially on the Feast of the Divine Mercy (19 April 2020). The feast is celebrated in the Catholic Church on the second Sunday of Easter and has a special character and meaning in the shrine in Łagiewniki. In the last few years, it attracted around 100 thousand pilgrims to the shrine. Because of the pandemic, for the first time in history the Feast of Mercy was celebrated in Łagiewniki without the attendance of crowds of pilgrims. In accordance with the guidelines of the Main Sanitary Inspector, only five people took part in Holy Masses celebrated in the Chapel of St. Joseph and at the Basilica. Pilgrims alternated to enter the shrine. Followers from all over the world could (and still can) connect with the Shrine of Divine Mercy spiritually via TV, radio and Internet broadcasts.

Until the outbreak of the pandemic, more than 50 thousand pilgrims and visitors from abroad (mostly from Slovakia, Italy, Germany, France, Austria, Czech Republic, Spain, Ukraine, the USA, the Philippines, Mexico, Canada and Brazil) were recorded each year at the Shrine of Divine Mercy in Łagiewniki (Mróz 2019b). As estimated by the spokesman of the Shrine, foreign visitors in 2020 accounted for only $3 \%$ of the numbers noted before the outbreak of the COVID-19 pandemic. The largest pilgrimages of foreigners to the shrine in Łagiewniki were cancelled, including, e.g. the Pilgrimage of Slovak People of the LUMEN Radio planned on 9 May (in recent years it gathered 20,000 pilgrims) and the Pilgrimage of the Greek Catholic Church from Slovakia scheduled for 23 May 2020. The First Pilgrimage of Vietnamese People which was to take place on 1-2 August 2020 was also cancelled.

After 30 May 2020, pilgrimages to the Shrine slowly revived. However, the pilgrimages in June and in the holiday months were definitely individualised. AllPoland pilgrimages were organised in the Shrine in August and September, but the attendance of pilgrims was definitely lower.

In response to the crisis in the functioning of the shrine during the pandemic, the shrine custodian and staff took various initiatives and implemented religious and 
spiritual as well as material projects. These included, for example, TV, radio and Internet broadcasts (online broadcast is available $24 \mathrm{~h}$ a day on the websites www. faustyna.pl and www.milosierdzie.pl) of services (Chaplet of the Divine Mercy) and the Holy Masses celebrated in the Shrine, the campaign of sending an image of Merciful Lord Jesus by post and the text of the Devotion to the Divine Mercy, placing an image of Merciful Lord Jesus on a $76 \mathrm{~m}$ tall tower organisation of parish pilgrimages to the Shrine and extension of the catering and accommodation offering in the pilgrimage zone of the Shrine-the state-funded Tourist Voucher can be used in the Pastoral Lodge, the Łagiewniki coffee can be bought at the Agape restaurant (it can also be ordered with delivery), handmade products such as a dumplings, stuffed cabbage rolls, croquettes can also be purchased. All this is offered in compliance with all sanitary procedures, as guaranteed by the "Safe Harbour" certificate granted to the Shrine by the Polish Tourism Organisation (miłosierdzie.pl).

\section{Religious Tourism to the Papal Town of Wadowice During the First Six Months of the SARS-Cov-2 Pandemic}

The Parliament of the Republic of Poland announced that the year 2020 would be the Year of Holy Father John Paul II. Celebrations of the hundredth anniversary of the birth of Karol Wojtyła-St. John Paul II were to be one of the main events of the year. The main jubilee celebrations were planned in Wadowice, the town where Karol Józef Wojtyła was born on 18 May 1920. The papal town of Wadowice belongs to the major pilgrimage centres in Central Europe. It houses numerous buildings associated with the youth of Karol Wojtyła. The most frequently visited sites include the Basilica of the Presentation of the Blessed Virgin Mary, the Family Home of John Paul II Museum and the Shrine of St. Joseph (Mróz 2007). It was possible to specify changes in tourism and pilgrimages (including their spatial range) to Wadowice during the last 25 years thanks to records of visitors to the Family Home of John Paul II Museum.

The greatest number of visitors and pilgrims to the Family Home of John Paul II Museum in Wadowice was recorded in 2005-431,391 people, including 53,850 visitors from abroad. This should be associated with the illness, death (2 April 2005) and funeral (8 April 2005) of John Paul II and the subsequent unprecedented religious revival of the Polish society (in May and June 2005 the museum was visited by a total of more than 140 thousand people). During the last five years (2014-2019), the museum noted more than 200 thousand visitors each year, including approximately 40 thousand foreigners from more than 100 countries (in 2015 the museum was visited by foreigners from 127 countries; in 2017 by visitors from 109 countries).

Considering the celebration of the hundredth anniversary of the birth of Karol Wojtyła, the year 2020 seemed to be the time of even more intense tourism and pilgrimage movement to Wadowice. A series of cultural and religious events were planned for the jubilee in the town and in individual sacred objects and the museum. In January and February 2020, the Family Home of John Paul II Museum recorded the highest number of visitors in the last decade: 5,579 and 7,202 people, 


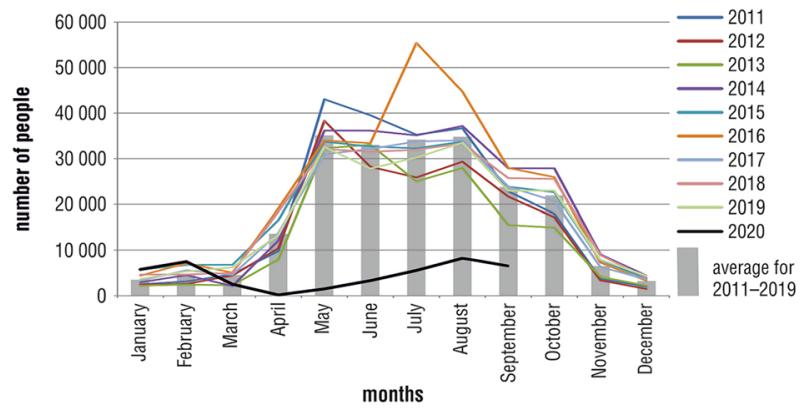

Fig. 6 Tourist visits to the Family Home of John Paul II Museum in Wadowice in individual months during the period of 2011-2020. Source: own study based on data made available by Family Home of John Paul II Museum in Wadowice

respectively (Fig. 6). On 12 March 2020, the museum was closed in accordance with the decision of the Minister of Culture and National Heritage. Due to the COVID19 pandemic, the official celebrations of the 100th anniversary of the birth of Karol Wojtyła in Wadowice which had been planned for months were cancelled. The museum was reopened on 18 May 2020.

The number of museum visitors counted from 18 May 2020 is considerably lower in comparison with similar months during the period of 2011-2019 (Fig. 6). This is obviously caused by the COVID-19 pandemic, including the imposed restrictions on visiting. From 18 May to 17 July 2020, the museum sold 135 tickets daily, from 18 July 2020 the number was increased to 270 tickets (only individual visits are possible). In June 2020, only 3,114 people were registered at the museum (in May 2019 the number was 32,590). Although tourism considerably increased in July and August (with 5,360 visitors in July and 8,027 in August), it was several times lower than in similar months in 2019. In September 2020, the Family Home of John Paul II Museum in Wadowice was visited by 6,499 people, i.e. only $28 \%$ of the number of visitors in September 2019.

\section{Discussion}

This paper presents the results of research on the influence of the COVID-19 pandemic on religious tourism and pilgrimages and on the pilgrimage space of selected Catholic shrines in Europe. This is the first research of this kind referring to European Christian pilgrimage centres in the era of COVID-19. The results can be of immense importance and can be referential to further research as these cover the first six months of the COVID-19 pandemic. From the perspective of the completion date of this publication (31/10/2020), it is clear that the period from March to September 2020 saw the first wave of the development of the SARS-Cov-2 coronavirus. Therefore, one care dare say that this is trend-setting research in the European pilgrimage space. 


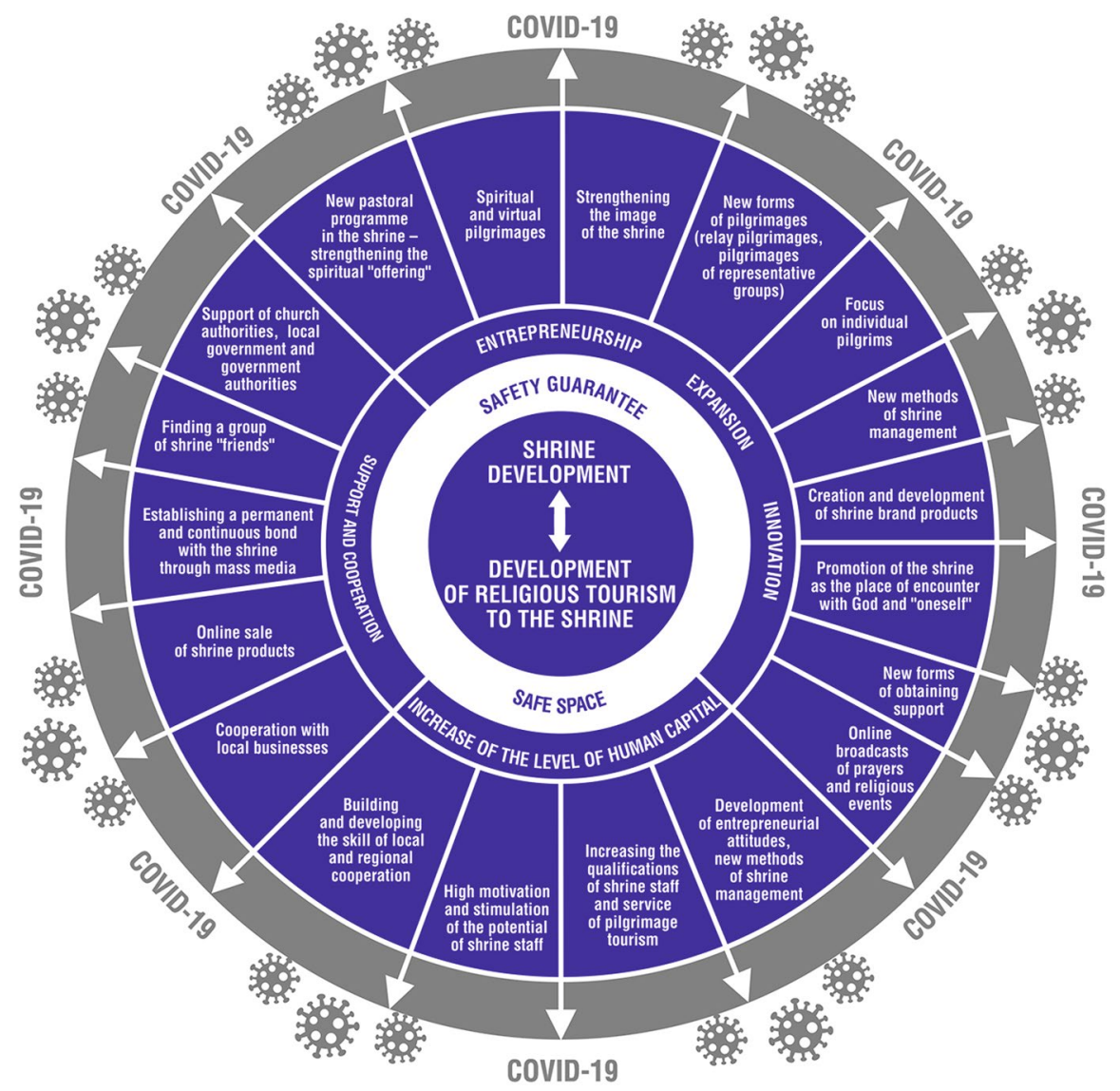

Fig. 7 The model of the development of shrines and pilgrimages to pilgrimage sites during the COVID19 pandemic. Source: own study

The research results given in this paper have been used to elaborate a model of the development of shrines and pilgrimages to pilgrimage sites during the COVID19 pandemic (Fig. 7). The development is possible if several factors are met: guarantee of safety, support and cooperation, increased level of human capital and entrepreneurship-innovation and expansion (Pineda-Albaladejo et al. 2020).

The primary factor is the guarantee of safety for pilgrims-tourists on their way to a pilgrimage centre and in the space of the shrine (Fig. 7). In this respect, the organisers of pilgrimages and hosts of shrines should take strict preventive measures in order to ensure safe space for both pilgrims and residents of pilgrimage centres. Thus, the reconstruction of pilgrimage and tourism facilities in shrines is necessary in order to guarantee sanitary safety. Traditional behaviours and habits of shrine visitors must change. This applies, for example, to the prohibition on touching or kissing relics, bathing in healing pools, using prayer mats, keeping social distancing (Oxholm et al 2020) There must be a limit imposed on the number of people staying in the designated zone of a holy site and in its very centre 
(shrine) at a time. Until the vaccine against COVID-19 is produced, it is justified to restrict and suspend mass congregations during religious events (Atique \& Itumalla 2020; Oxholm 2020). The principles of sanitary safety must also apply within the area of tourism infrastructure on pilgrimage routes leading to the shrine (https://www.who.int/publications/i/item/10665-332235). Camino de Santiago in the Iberian Peninsula and pilgrimage routes to the Marian Shrine in Jasna Góra (Poland) are examples of good practices in this area. When it comes to Jasna Góra, the traditional pilgrimages on foot of thousands of people have been replaced during the pandemic by relay pilgrimages, pilgrimages with a limit on the number of the faithful or pilgrimages of representative groups.

Until the pandemic has subsided, shrines will find it difficult to develop without the support of church authorities, regional and central authorities and cooperation of shrine custodians with businesses and tour operators organising pilgrimages and tourism excursions. The sharing of experiences and cooperation of shrine custodians and hosts (mayors) of cities and towns where shrines are housed will be really valuable.

It seems equally important to find a group of friends who will support the development of the centre, to cooperate with local businesses, to keep strengthening the shrine's image and to create and develop brands of products sold at shrines. During the first wave of the COVID-19 pandemic, the largest Catholic shrines in Europe (but also shrines of other religions) encouraged pilgrims to increase their participation in online services and prayers and to go on virtual spiritual pilgrimages. The use of the mass media (mainly television and social media) in pilgrimage ministry will be an important factor to deepen the bond between a pilgrim and a shrine during the coronavirus era. Online broadcasts of religious celebrations and events at the shrine (giving blessings to pilgrims in many languages), online access to museum collections and the possibility of virtual visits to pilgrimage centres are important in this regard (Romano 2007). The largest Catholic shrines appeal via the Internet and social media for help, donations and financial support, e.g. through online sale of shrine products or the lighting of a "virtual candle".

The UN World Tourism Organisation (UNWTO) emphasises that human capital will be necessary for the development of global tourism. Increased human resources will also be needed for the development of shrines and tourism to pilgrimage centres. Therefore, even greater emphasis must be laid on professional staff for the service of pilgrimages and tourism who are highly motivated and have the right attitude, are keen on raising their qualifications and exhibit entrepreneurial attitudes. Both shrine managers and staff of pilgrimage centres should be characterised by perseverance and flexibility in the pursuance of their goals, skills and reliability in the cooperation with inner circles and the surroundings and courage to take decisions in the era of constant changes. Innovation and expansion-seeking new ideas, solutions and projects, implementing them, observing and drawing the right conclusions or taking adequate preventive measures, are subsequent keys to success in the development of shrines during the post-COVID-19 time. 


\section{Conclusions and Future Research}

Research has shown that the global range of the pandemic, restricted mobility, isolation of hundreds of millions of people worldwide have had a dramatic or even tragic influence on the functioning of pilgrimage centres or pilgrimage towns, as the example of Lourdes shows. The traditional regular pilgrimage movement has radically changed.

The number of pilgrimages and tourists to Catholic shrines in Europe decreased by $90-95 \%$ during the first six months of the COVID-19 pandemic. The pilgrimage space of shrines has greatly changed, not only in terms of the number of visitors but also the age structure of pilgrims (a distinct decrease in the number of pilgrims aged $60+$ ) and reasons for going on pilgrimages to shrines. A lot of shrines were closed during the first weeks of the pandemic (from mid-March to May), and some remained closed even until June. In the contemporary times, we have not noted such a scale of global changes due to any other epidemic. It is an unimaginable event which cannot be compared to any other phenomenon.

It is also worth looking at positive aspects related to pilgrimages and religious tourism during the first wave of the COVID-19 pandemic. The first positive aspect is an increase in individual pilgrimages along local pilgrimage routes and visits to national, regional and local pilgrimage centres. For some, a sort of "Caminoholism" or "addiction" to walking along pilgrimage routes (not only Camino de Santiago) and a longing for "being on the road and taking a deep insight into oneself", was what helped them overcome fear of the coronavirus and take up local pilgrimage routes. Due to this longing for pilgrimages and visits to sacred sites expressed by thousands of people not only on social media, people came closer to one another, started to show solidarity to those ill, supported their favourite shrines financially and began to plan pilgrimages in the future, after the era of COVID-19 comes to an end. Pilgrims' diaries of virtual pilgrimages during the pandemic are also an interesting topic for research. It should also be emphasised that closer cooperation between custodians/rectors of shrines was established in order to share experiences related to the organisation and service of pilgrimages to shrines. Online conferences which saw participation of representatives of shrines in Altötting, Częstochowa, Einsiedeln, Fatima, Loreto, Lourdes and Mariazell can be quoted as examples here.

From the perspective of the completion date of work on the publication (31 October 2020), we know that research should be continued due to the further development of the COVID-19 pandemic. It will be important to examine the economic consequences of the development of the SARS-Cov-2 coronavirus for the space of pilgrimages to pilgrimage centres. Further studies on the impact of the COVID-19 pandemic should also cover local pilgrimage centres.

\section{Compliance with Ethical Standards}

Conflict of interest The author declares no conflict of interest. 


\section{References}

Adamczyk, S. (2011). Zasługi papieża Kaliksta II (1119-1124) w szerzeniu kultu św. Jakuba Apostoła. In: A. Jackowski, F. Mróz, \& I. Hodorowicz (Eds.), Wpływ Świętego Roku Jakubowego na rozwój kultu i Drogi św. Jakuba (pp. 53-54). Wydawnictwo „Czuwajmy”.

Apollo, M., Wengel, Y., Schänzel, H., \& Musa, G. (2020). Hinduism, ecological conservation and public health: what are the health hazards for religious tourists at hindu temples? Religions, 11, 416.

Atique, S., \& Itumalla, R. (2020). Hajj in the time of COVID-19. Infection, Disease and Health. https:// doi.org/10.1016/j.idh.2020.04.001.

Bordas Prószyński, B. (2020). Stan alarmu na terenie Hiszpanii. In: https://phig.pl/pl/media/artyk uly/293/2020/03/16/stan-alarmu-na-terenie-hiszpanii

Bronk, K. (2020). Mniej pielgrzymów na Camino, więcej na trasach lokalnych. In: www.vaticannews.va/ pl/kosciol/news/2020-09/mniej-pielgrzymow-w-europie.html

Cazaux, F. (2011). To be a pilgrim: A contested identity on Saint James' Way, tourism. An International Interdisciplinary Journal, 59, 353-367.

Chélini, J., \& Branthomme, H. (1982). Les chemins de Dieu. Histoire des pèlerinages chrétiens des origines à nos jours. Hachette.

Cohen, E. (1992). Pilgrimage centres: Concentric and excentric. Annals of Tourism Research, 19(1), 33-50.

Coleman, S., \& Eade, J. (2004). Reframing Pilgrimage. Cultures in Motion. Routledge.

Collins-Kreiner, N. (2007). Graves as Attractions: Pilgrimage-tourism to Jewish Holy Graves in Israel. Journal of Cultural Geography, 24, 67-89.

Collins-Kreiner, N. (2010). The geography of pilgrimage and tourism: Transformations and implications for applied geography. Applied Geography, 20, 153-164.

Collins-Kreiner, N. (2015). Dark tourism as/is pilgrimag. Current Issues in Tourism, 19, 1185-1189.

Digance, J. (2003). Pilgrimage at contested sites. Annals of Tourism Research, 301, 143-159.

Eade, J., \& Sallnow, M. (1991). Contesting the Sacred. The Anthropology of Christian Pilgrimage. Routledge.

Eliade, M. (1969). The quest: History and meaning in religion. University of Chicago Press, Chicago.

Griffin, K., \& Raj, R. (2017). The importance of religious tourism and pilgrimage: Reflecting on definitions, motives and data. International Journal of Religious Tourism and Pilgrimage, 5, 152.

Gusmán, I., Lopez, L., González, R. C. L., \& Santos, X. M. (2017). The challenges of the first European cultural itinerary: The way of St James. Almatourism Special Issue, 6, 1-19.

Jackowski, A. (2003). Święta przestrzeń świata. Podstawy geografii religii. Wydawnictwo Uniwersytetu Jagiellońskiego.

Jackowski, A. (2005). Jasnogórskie pielgrzymowanie bez granic. Częstochowa: Tygodnik Katolicki „Niedziela”.

Jackowski, A., \& Mróz, F. (Eds.). (2012). »Akt Europejski« bł. Jana Pawła II, a renesans Drogi św. Jakuba w Europie. Wydawnictwo „Czuwajmy”.

Kaszowski, L. (1996). Chrześcijańskie spojrzenie na środowisko geograficzne jako przestrzeń pielgrzymowania. Peregrinus Cracoviensis, 4, 75-91.

Mróz, F. (2007). Tu, w tym mieście, w Wadowicach, wszystko się zaczęło... Pielgrzymowanie i turystyka religijna do miasta rodzinnego Karola Wojtyły. Peregrinus Cracoviensis, 18, 77-96.

Mróz, F. (2016). Sanktuaria Kościoła Rzymskokatolickiego w przestrzeni sakralnej Polski. In J. Latosińska, \& J. Mokras-Grabowska (Ed.), Kultura i turystyka. Sacrum i profanum (pp. 183-205). Łódź: Regionalna Organizacja Turystyczna Województwa Łódzkiego.

Mróz, F. (2017). How has camino developed? Geographical and historical factors behind the creation and development of the way of St. James in Poland. In E. Alarcon, \& P. Roszak (Ed.), The Way of St. James: Renewing insights (pp. 59-80). Eunsa.

Mróz, F. (2019b). Kraków w przestrzeni pielgrzymkowej świata. Potencjał i perspektywy rozwoju turystyki religijnej stolicy Małopolski. Annales Universitatis Paedagogicae Cracoviensis Studia Geographica, 13, 40-56.

Mróz, F. (2019a). 6900 km oznakowanych odcinków Camino de Santiago w Polsce - sukcesy, niepowodzenia i wyzwania. In: P. Roszak, F. Mróz, \& W. Rozynkowski (Eds.), Camino Polaco. Teologia - Sztuka - Historia - Teraźniejszość (pp. 267-299). Wydawnictwo Naukowe Uniwersytetu Mikołaja Kopernika. 
Mróz, F. (2020). Poles travelling to compostela in time and space. Journal of Cultural Geography. https:// doi.org/10.1080/08873631.2020.1864086.

Mróz, F., Mróz, Ł, \& Krogmann, A. (2019). Factors conditioning the creation and development of a network of Camino de Santiago routes in Visegrad Group countries. International Journal of Religious Tourism and Pilgrimage, 7, 56-71.

Murray, M., \& Graham, B. (1997). Exploring the dialectics of route-based tourism: The camino de santiago. Tourism Management, 18, 513-524.

Oxholm, T., Rivera, C., Schirrman, K., \& Hoverd, W. J. (2020). New Zealand religious community responses to COVID-19 while under level 4 lockdown. Journal of Religion and Health, 9, 526.

Pineda-Albaladejo, J. M., López Puga, J., \& Moya-Faz, F. J. (2020). La espiritualidad de la educación integral como factor de bienestar bioético y sostenible. Scientia et Fides, 1, 205-219.

Romano, J. F. (2007). Liturgy and Pilgrimage. Koninklijke Brill NV, Leiden: In Encyclopedia of Medieval Pilgrimage.

Roszak, P. (2017). Pilgrimage as sacramentum peregrinationis? Discovering the Ecclesiological Background of the Camino de Santiago. In E. Alarcon, \& P. Roszak (Ed.), The Way of St. James: Renewing Insights (pp. 137-157). Eunsa.

Roszak, P. (2019). Sacred and space in post-secular pilgrimage: The Camino de Santiago and relational model of the sacred. International Journal of Religious Tourism and Pilgrimage, 7, 33-40.

Scaffidi Abbate, C., \& Di Nuovo, S. (2013). Motivation and personality traits for choosing religious tourism. A research on the case of Medjugorje. Current Issues in Tourism, 16(5), 501-506.

Singh, S. (2004). Religion, heritage and travel: Case references from the Indian Himalayas. Current Issues in Tourism, 7(1), 44-65.

Timothy, D., \& Olsen, D. (Eds.). (2006). Tourism, religion and spritiual journeys. London: Routledge.

Publisher's Note Springer Nature remains neutral with regard to jurisdictional claims in published maps and institutional affiliations. 